\title{
Soft thermoplastic silicone elastomer via supramolecular chemistry
}

\author{
Jeong, Seonghyeon; Daugaard, Anders E.; Skov, Anne L.
}

Publication date:

2020

Document Version

Publisher's PDF, also known as Version of record

Link back to DTU Orbit

Citation (APA):

Jeong, S., Daugaard, A. E., \& Skov, A. L. (2020). Soft thermoplastic silicone elastomer via supramolecular chemistry. Poster session presented at American Chemical Society Fall 2020 Virtual Meeting \& Expo.

\section{General rights}

Copyright and moral rights for the publications made accessible in the public portal are retained by the authors and/or other copyright owners and it is a condition of accessing publications that users recognise and abide by the legal requirements associated with these rights.

- Users may download and print one copy of any publication from the public portal for the purpose of private study or research.

- You may not further distribute the material or use it for any profit-making activity or commercial gain

- You may freely distribute the URL identifying the publication in the public portal

If you believe that this document breaches copyright please contact us providing details, and we will remove access to the work immediately and investigate your claim. 
